\title{
ENHANCING UNDERSTANDING OF HISTORICAL TIME IN PRIMARY CLASSES: HOW TO IMPROVE THE CURRICULUM IN LITHUANIA?
}

\author{
Aušra Žemgulienè \\ Institute of Educational Sciences, Faculty of Philosophy (Lithuania)
}

\begin{abstract}
History teaching has been raising many didactic issues recently. First, the concept of the very discipline of history has been undergoing changes, the aim of school education is being shifted from memorizing pre-defined content towards developing historical literacy based on critical thinking and development of historical research skills. Second, admitting the impact of socio-cultural context on pupil achievement, the attitude towards children's receptive skills and their development has been gaining new perspectives. This is of high importance in primary education, where a heroic story is often still dominant. At present, the discourse of primary education curriculum change emphasizes attractive communication of scientific knowledge and the demand for active research to broaden children's deep understanding. However, the development of historical literacy in primary classes still remains to be complicated since, on the one hand, it requires new landmarks - what and how to teach, on the other hand, research in this field has been very limited.

In Lithuania, there is an intention to re-new the curricula in all the fields. Therefore, it becomes relevant to analyse what skills to understand historical time should be developed in primary classes. This scientific problem is solved by carrying out a qualitative analysis of the content of primary education curriculum. Based on the chosen model of understanding historical time (De Groot-Reuvekamp, Ros, Van Boxtel, Oort, 2015), this article analyses the extent to which curriculum requirements of history teaching correspond to the goals and comprehension levels of the model of understanding historical time (A - Emergent; B - Initial; C - Continued) and what should be improved when updating the curriculum. The research results reveal that the present curriculum requirements for the 4th year pupils are inadequately low. They lead towards the stage of acquiring understanding (A - Emergent) rather than Initial (B) or Continued (C) stages. Therefore, while revisiting the curriculum, it is important to pay more attention to the development of historical research and higher thinking skills, that would be a significant step towards gaining deeper understanding of historical time.
\end{abstract}

Keywords: Understanding of historical time, history teaching in primary classes, curriculum.

\section{Introduction}

The aim of history learning is now being shifted from learning facts and dates to constructing a narrative, which is based on analysing, interpreting and finding arguments for the past (Barton, Levstik, 2004; Lee et al., 1993; Lee, 2005). Under the influence of constructivist ideas, history learning is considered to be the process of investigating and creating historical knowledge, during which pupils reconstruct their previous knowledge and develop their understanding (Levstik, Barton, 2015; Cooper, 2002; Seixas, 1996). It is considered that the progress of understanding of history is reflected not by the amount of knowledge, but by deeper understanding of this knowledge and by certain cognitive constructs that are developed individually (Lee, 2005). The comprehension of time is the key ability when learning history. Evidence shows that it is related not only with the age. Primary school children are able to develop complex structures of historical thinking, when they have the context of content adapted to them, learning material prepared, and intensive activity of investigation organized for them (Barton, Levstik, 2004; Cooper, 2011). Younger children sometimes have deeper reasoning skills than older children (Lee et al., 1993; Stow, Haydn, 2000; De Groot-Reuvekamp et al., 2014), which leads us to an assumption that the basics of understanding historical time are acquired earlier that the adolescent age. However, it is not a typical practice in the primary school. In terms of developing the basics of historical literacy, the contexts of various countries differ, and research in this field is limited.

\section{Context}

Many authors have researched various aspects of time comprehension, and in general, the following goals of education can be distinguished: understanding the vocabulary of historical time; understanding sequence; understanding contextual features; understanding historical periods. With yet 
another goal added, i.e. the goal of applying timeline, the model of developing the understanding of historical time is created, which enables us to identify, develop, and assess pupils' achievement from the age of 6 to 12 (De Groot-Reuvekamp, 2016; 2017). This model combines 5 educational goals and the implementation of these goals through three developmental stages of achievement: A (Emergent) emergence of understanding (the very basics); B (Initial) - initial (developing) understanding; $\mathrm{C}$ (Continued) - growing (continued) understanding. The model is based on the following principles: children's vocabulary of time develops from broad and general expressions (long time ago) to indicating specific dates; and children's understanding about evolution and changes expands from specific knowledge to abstract knowledge. According to research, the transition between the three stages of understanding takes place individually, therefore, the model is not linked to children's age (De Groot-Reuvekamp, 2017, p.41-42). These insights are important when defining the guidelines of the curriculum, but is this what we are trying to achieve? In Lithuania, for instance, the teaching of history in primary school ${ }^{1}$ is integrated into the subject of World Studies. The curriculum covers six areas, where the area of The Changes in People's Living is dedicated to history (Primary Education Curriculum, 2008). The content covers history periods of this country and the world, the topics are usually taught in a chronological manner. However, how does the curriculum set the background for understanding historical time? In this stage of the research, an attempt was made to answer this question with the aim to analyse the content of the Lithuanian Primary Education Curriculum by identifying the requirements of understanding historical time for pupils and the extent to which these requirements correspond to the chosen model of developing the understanding of historical time. This analysis will complement the field of research of understanding historical time in Lithuania with contextual data. Since qualitative content analysis has the benefit of comparing data, it can be useful to researchers who are interested in the contexts of other countries.

\section{Methods}

The method of content analysis was chosen for the research, which works well for describing and interpreting written artefacts (White, Marsh, 2006), contextualizing the field of problem, and raising questions related to the area of research (Bowen, 2009). The curriculum reflects national goals, the expectations for pupils' achievements, and education guidelines for teachers. It reveals the context in which education takes place. The data was collected through the analysis of the World Studies curriculum of the Lithuanian primary education, as the text of a public document. Since qualitative content analysis helps identify models and fill them with data (Fereday, Muir-Cochrane, 2006), the decision was made to analyse the document on the grounds of the already developed construct. The model of developing the understanding of historical time was chosen to be this construct; it is broadly described by the researchers of this area (De Groot-Reuverkamp et al., 2014; De Groot-Reuvekamp, 2017). The model was approached as the topic of understanding the time, which integrates educational goals as categories. Each category consists of three subcategories, i.e. comprehension stages in the order of progression: A (Emergent) - emergence of understanding (the very basics); B (Initial) - initial (developing) understanding; C (Continued) - growing (continued) understanding (De Groot-Reuvekamp, Harnet, 2016; De Groot-Reuvekamp, 2017). The content of curriculum was investigated by the principle of thematic analysis with the purpose of finding and identifying the units of meaning, i.e. statements which describe the knowledge and abilities of understanding time. The statements found were allocated to the categories and subcategories of the chosen construct as codes according to their meaning. The selection of codes was carried out according to the extent to which these statements correspond to the topic of developing the understanding of time and to the structure of the chosen model. Various general observations that contain no expectations for achievements were rejected, for instance, "to have sufficient knowledge of historical images" (Primary Education Curriculum, 2008, 243). The results were interpreted in the hermeneutical manner by analysing the expectations for achievements as a phenomenon of investigation.

\section{Results}

The content of the Lithuanian Primary Education Curriculum consists two blocks, i.e. the one for the $1^{\text {st }}$ and the $2^{\text {nd }}$ grades, and the other for the $3^{\text {rd }}$ and the $4^{\text {th }}$ grades. The investigation looked into the statements of both blocks; these statements were included in the curriculum as requirements for pupils' knowledge and abilities of understanding the time. The data is provided in Tables 1-5; they are analysed and interpreted with reference to the data of empirical research on pupils' achievements.

\footnotetext{
${ }^{1}$ In Lithuania primary education starts at the age of 7 and lasts for 4 years.
} 
Table 1. Understanding of notions.

\begin{tabular}{|c|c|c|c|}
\hline \multirow[t]{2}{*}{ Category } & \multirow[t]{2}{*}{ Subcategory } & \multicolumn{2}{|c|}{ Statements found in the curriculum of World Studies subject } \\
\hline & & $1^{\text {st }}-2^{\text {nd }}$ grade & $3^{\text {rd }}-4^{\text {th }}$ grade \\
\hline \multirow[t]{3}{*}{$\begin{array}{l}\text { Pupils } \\
\text { understand } \\
\text { and use the } \\
\text { vocabulary } \\
\text { of time and } \\
\text { historical } \\
\text { periods }\end{array}$} & $\begin{array}{l}\text { A (Emergent) - relative notions } \\
\text { of time; notions of calendar time }\end{array}$ & $\begin{array}{l}\text { To understand the notions which express the } \\
\text { changes of time. To express the understanding of } \\
\text { time flow and time change: to distinguish and } \\
\text { properly use the following notions: yesterday, } \\
\text { today, tomorrow; in the past, at the present, in the } \\
\text { future; a day, a week, a month, a year. }\end{array}$ & $\begin{array}{l}\text { To use the notions of time in a fluent and } \\
\text { proper manner. }\end{array}$ \\
\hline & $\begin{array}{l}\text { B (Initial) - certain periods; } \\
\text { "labels"; AD dates }\end{array}$ & No statements found & $\begin{array}{l}\text { To have a general understanding of the } \\
\text { key facts of the Lithuanian history. To } \\
\text { distinguish several most prominent } \\
\text { moments in the Lithuanian history (either } \\
\text { of the two). }\end{array}$ \\
\hline & $\begin{array}{l}\text { C (Continued) - terminology of } \\
\text { periods; centuries and dates } \\
\text { AD/BC }\end{array}$ & No statements found & No statements found \\
\hline
\end{tabular}

Table 2. Understanding sequence (chronology).

\begin{tabular}{|c|c|c|c|}
\hline \multirow[t]{2}{*}{ Category } & \multirow[t]{2}{*}{ Subcategory } & \multicolumn{2}{|c|}{ Statements found in the curriculum of World Studies subject } \\
\hline & & $1^{\text {st }}-2^{\text {nd }}$ grade & $3^{\text {rd }}-4^{\text {th }}$ grade \\
\hline \multirow{3}{*}{$\begin{array}{l}\text { Pupils put } \\
\text { objects of } \\
\text { various } \\
\text { historical } \\
\text { periods in the } \\
\text { chronological } \\
\text { order }\end{array}$} & $\begin{array}{l}\text { A (Emergent) - } \\
\text { specific objects }\end{array}$ & $\begin{array}{l}\text { To describe some facts of greater importance } \\
\text { about your family members. To understand } \\
\text { the links between grandparents, parents, } \\
\text { children. To have basic understanding of } \\
\text { historical change and continuity. To } \\
\text { understand the notions of change and } \\
\text { alteration. }\end{array}$ & $\begin{array}{l}\text { To point to examples of man-made values, such as } \\
\text { castles, palaces, churches, works of art. To sequence } \\
\text { historical events in a chronological order by using } \\
\text { everyday terms (previously, now, in the future; } \\
\text { earlier, later; some time ago, at some point, etc.). }\end{array}$ \\
\hline & $\begin{array}{l}\text { B (Initial) - objects } \\
\text { of several periods }\end{array}$ & No statements found & $\begin{array}{l}\text { To know the most famous local people; to know the } \\
\text { most important local historical monuments. }\end{array}$ \\
\hline & $\begin{array}{l}\text { C (Continued) - } \\
\text { objects of historical } \\
\text { periods }\end{array}$ & No statements found & No statements found \\
\hline
\end{tabular}

Table 3. Applying timeline.

\begin{tabular}{|l|l|l|l|}
\hline Category & Subcategory & \multicolumn{2}{|l|}{ Statements found in the curriculum of World Studies subject } \\
\cline { 2 - 4 } & $\mathbf{1}^{\text {st }}-\mathbf{2}^{\text {nd }}$ grade & $\mathbf{3}^{\text {rd }}-\mathbf{4}^{\text {th }}$ grade \\
\hline $\begin{array}{l}\text { Pupils properly } \\
\text { place objects, } \\
\text { events and } \\
\text { personalities on } \\
\begin{array}{l}\text { a timeline } \\
\text { timeline from earlier to nowadays }\end{array}\end{array}$ & $\begin{array}{l}\text { No statements found } \\
\text { B (Initial) - a timeline with } \\
\text { names of periods }\end{array}$ & No statements found \\
\cline { 2 - 4 } & $\begin{array}{l}\text { N (Continued) - a timeline with } \\
\text { centuries and dates (AD and BC) }\end{array}$ & No statements found & $\begin{array}{l}\text { To understand how one period replaces the } \\
\text { previous one. To name the periods of history (not } \\
\text { necessarily in the chronological order). }\end{array}$ \\
\hline
\end{tabular}

Table 4. Identifying characteristic features.

\begin{tabular}{|l|l|l|l|}
\hline Category & Subcategory & Statements found in the curriculum of World Studies subject \\
\cline { 2 - 4 } & & $\mathbf{1}^{\text {st }}-\mathbf{2}^{\text {nd }}$ grade & $\mathbf{3}^{\text {rd }}-\mathbf{4}^{\text {th }}$ grade \\
\hline $\begin{array}{l}\text { Pupils identify / } \\
\text { apply the features } \\
\text { according to } \\
\begin{array}{l}\text { which they } \\
\text { ascribe objects, } \\
\text { events, situations } \\
\text { or people to a } \\
\text { certain period }\end{array}\end{array}$ & $\begin{array}{l}\text { A (Emergent) - everyday features of } \\
\text { periods }\end{array}$ & $\begin{array}{l}\text { To give specific examples to } \\
\text { illustrate people's life in the } \\
\text { past and in the present. To } \\
\text { describe houses, clothes, work } \\
\text { tools of ancient people. }\end{array}$ & $\begin{array}{l}\text { To generally describe the signs of the past of } \\
\text { one's place of living. To identify the great } \\
\text { periods of history according to characteristic } \\
\text { features (signs). }\end{array}$ \\
\cline { 2 - 4 } & $\begin{array}{l}\text { B (Initial) - social and cultural } \\
\text { features of certain periods }\end{array}$ & $\begin{array}{l}\text { To describe how fire was used } \\
\text { in ancient times, what animals } \\
\text { were domesticated first; what } \\
\text { means of transport and } \\
\text { communication existed then } \\
\text { and what exists now. }\end{array}$ & $\begin{array}{l}\text { To explain what people were occupied with in } \\
\text { ancient times (picking, hunting, fishing), later on } \\
\text { when work tools were invented and animals } \\
\text { domesticated (agriculture, husbandry, crafts), } \\
\text { and in more recent times (construction of } \\
\text { castles, towns, roads and bridges, creation of } \\
\text { art). }\end{array}$ \\
\cline { 2 - 4 } & $\begin{array}{l}\text { C (Continued) - socio-cultural, } \\
\text { economic and political features of the } \\
\text { country and the world }\end{array}$ & No statements found & No statements found \\
\hline
\end{tabular}

Table 5. Comparing historical periods.

\begin{tabular}{|c|c|c|c|}
\hline \multirow[t]{2}{*}{ Category } & \multirow[t]{2}{*}{ Subcategory } & \multicolumn{2}{|c|}{ Statements found in the curriculum of World Studies subject } \\
\hline & & $1^{\text {st }}-2^{\text {nd }}$ grade & $3^{\text {rd }}-4^{\text {th }}$ grade \\
\hline \multirow{3}{*}{$\begin{array}{l}\text { Pupils compare } \\
\text { and contrast } \\
\text { various historical } \\
\text { periods according } \\
\text { to their } \\
\text { similarities, } \\
\text { differences and } \\
\text { changes }\end{array}$} & $\begin{array}{l}\text { A (Emergent) - examples of the past / } \\
\text { present from stories told by parents and } \\
\text { grandparents }\end{array}$ & $\begin{array}{l}\text { To give examples about the alterations } \\
\text { of one's living place. }\end{array}$ & $\begin{array}{l}\text { To compare people's lifestyles, } \\
\text { occupations, leisure in the past } \\
\text { and in the present. }\end{array}$ \\
\hline & $\begin{array}{l}\text { B (Initial) - similarities, differences and } \\
\text { changes of people's lives during different } \\
\text { periods }\end{array}$ & $\begin{array}{l}\text { To identify, understand, assess and } \\
\text { describe the changes in the immediate } \\
\text { natural and social environment. }\end{array}$ & No statements found \\
\hline & $\begin{array}{l}\text { C }(\text { Continued })-\text { similarities, differences and } \\
\text { changes of people's lives during different } \\
\text { periods }\end{array}$ & No statements found & No statements found \\
\hline
\end{tabular}


The results reveal that statements found in the curriculum do not include scientific notions of historical time, such as the century, era, period. We only see the notions of calendar time in the first block $\left(1^{\text {st }}-2^{\text {nd }}\right.$ grades $)$, whereas the expectations for using notions remained unclear in the second block $\left(3^{\text {rd }}-4^{\text {th }}\right.$ grades $)$. A question arises as to what notions older pupils should use in "a fluent and proper manner". The curriculum states that $3^{\text {rd }}$ and $4^{\text {th }}$ graders should acquire "general understanding about $\langle\ldots>$ facts" and "to distinguish several <..> moments". Shouldn't facts be linked to the names of periods? Children usually do that through "labelling" periods or indicating dates (Hoodles, 2002; Cooper, 2002; Wilshut, 2010). The Lithuanian research has shown that 9-year-olds use descriptions such as a Stone Age man, a Roman warrior (Žemgulienè, Balcevič, 2017, p. 154-155). As many as $76.8 \%$ of fourth-graders were able to identify the era for the given statements, whereas $52.8 \%$ were able to identify the century, and $29.2 \%$ said that the knight lived in the Middle Ages (Žemgulienè, 2017, p. 427- 429). It means they used the "labels" for periods, and some of them used scientific notions; it corresponds to level B (Initial) and partially to level $\mathrm{C}$ (Continued) of the chosen model. Why these abilities are not identified as expectations for pupils' learning outcomes?

Teaching chronology is done through the content which is taught according to the principle of knowing the immediate environment first. For the $1^{\text {st }}-2^{\text {nd }}$ graders the topics cover relationship of children, parents and grandparents, their items, lifestyles, occupations, traditions. However, the curriculum only refers to knowledge, not abilities. In higher grades the knowledge is extended to studying events and personalities related to the place of living, the country and the world. However, statements that describe abilities refer to expectations for the abilities of grouping instead of sequencing. It is a low expectation for the second block, since children as early as at the age of 6 or 7 are able to group according to the principle earlier-nowadays, whereas older pupils can put objects of several periods in a sequence (Barton, Levstik, 2004; Davson, 2007; Cooper, 2015). Data obtained from the Lithuanian research also revealed that the images of a warrior were correctly sequenced by $59.1 \%$ of fourth-graders (Žemgulienè, 2017 , p. 429). Why is it not an expectation for pupils' achievements?

It is obvious that the curriculum does not intend to develop the abilities of applying a timeline. The requirement to name the periods is questionable: why should pupil know about them if the curriculum does not care about their sequence? It does resemble the expectation for memorizing. Research results reveal that pupils of both blocks would be able to develop these abilities if only they are taught to do so (De Groot Reuvekamp, 2017, p. 52-53). Such research has never been carried out in Lithuania.

The abilities to identify features are developed at level A (Emergent) and level B (Initial) of the model. However, the meanings behind the statements do not reflect expectations for the progress of achievements. The statements in both blocks are related to knowledge. The statements in the first block ask pupils to describe features, whereas in the second block they are asked to explain. However, what periods should this knowledge cover? It remains unclear. The curriculum refers to the past as to "ancient times" and "more recent times", which is entirely improper when teaching the understanding of time (Stow, Haydn, 2000; Hoodkinson, 2003; 2004; Wilshut, 2010). Research demonstrates that primary school children are able of noticing changes in objects and technological advance (Levstik, Barton, 1994; Wilshut, 2010), however, they are typically able to indicate contextual features by referring to a given text rather than to contemplations of a particular period (Van Drie, Van Boxtel, 2008). Lithuanian pupils are also better at sequencing rather than explaining why they did so (Žemguliené, 2017). Why it is not taught?

Descriptions of achievements in terms comparing historical periods correspond to level A (Emergent) and level B (Initial). However, the comparison given in the second block based on the principle earlier-nowadays is too low an achievement, since much younger children are capable of making such a comparison (Hoodles, 2002). On the contrary, the expectation for evaluating the social environment is too high in the first block, since it is more difficult for younger children to perceive social changes (De Groot Reuvekamp, 2017, p. 50). Nevertheless, as many as $58.6 \%$ of fourth-graders in Lithuania made a correct link between secret teaching and the occupation by tsarist Russia (Žemgulienè, 2017, p. 431). It is, however, too difficult for the second-graders.

\section{Conclusion}

The Lithuanian Primary Education Curriculum provides for the teaching of all goals of the model of developing the understanding of historical time at level A (Emergent), and the some of the goals are taught at level B (Initial). None of the goals are taught at comprehension level C (Continued). Research suggests that the majority of 10-year-olds achieve level B in terms of all goals, and some of them achieve abilities of level C. However, the integrated curriculum does not provide for the development of such levels of historical literacy. The curriculum is subject to improvement in terms of all these aspects. 


\section{References}

Barton, K. C., Levstik, L. S. (2004). Teaching History for the Common Good. New Jersey-London, Lawrence Erlbaum Associates, Inc.

Bowen, G. A. (2009). Document analysis as a qualitative research method. Qualitative Research Journal, 9(2), 27-40. doi:10.3316/QRJ0902027.

Cooper, H. (2002). History in the Early Years (first published 1995 by Routledge). Taylor \& Francis e-Library, 2002.

Cooper, H. (2011). What Does it Mean to Think Historically in the Primary School? In L. Perikleous, D. Shemilt (Eds.) The Future of the Past: Why History Education Matters (pp. 321-342).

Cooper H. (2015). How Can We Plan for Progression in Primary School History?* In Revista de Estudios Sociales No. 52, p. 16-31. doi. http://dx.doi.org/10.7440/res52.2015.02.

Davson, I. (2007). Time for chronology. Teaching History, 117, 14-24.

De Groot-Reuvekamp, M., \& Harnett, P. (2016). How do pupils understand historical time? Some evidence from England and the Netherlands. Primary History, 73, 6-9.

De Groot-Reuvekamp, M. J., Van Boxtel, C., Ros, A., Harnett, P. (2014). The understanding of historical time in the primary history curriculum in England and the Netherlands. Journal of Curriculum Studies, 46(4), 487-514. doi.org/10.1080/00220272.2013.869837.

De Groot-Reuvekamp, M. J. (2017). Timewise: Improving pupils' understanding of historical time in primary school. PhD thesis. Amsterdam School of Historical Studies (ASH). P. 156. Retrieved from: https://dare.uva.nl/search?identifier=b7f872f9-d8b1-4314-a0c7-d71e9da5e8bb

Fereday, J. \& Muir-Cochrane, E. (2006). Demonstrating rigor using thematic analysis: A hybrid approach of inductive and deductive coding and theme development. International Journal of Qualitative Methods, 5(1), 80-92.

Hodkinson, A. (2003). History howlers: amusing anecdotes or symptoms of the difficulties children have in the retention of historical knowledge. Some observations based on recent research. Research in Education, 70, 21-36. doi: 10.7227/RIE.70.3.

Hodkinson, A. (2004). Does the English Curriculum for history and its schemes of work effectively promote primary-aged children's assimilation of the concepts of historical time? Some observations based on current research. Educational Research, 46(2), 99-117. doi.org/10.1080/0013188042000222403.

Hoodless, P. A. (2002). An investigation into children's developing awareness of time and chronology in story. Journal of Curriculum Studies, Issue 2(34), 173-200. doi.org/10.1080/00220270110080962.

Lee, P. et al. (1993). Progression in Children's Ideas about History. Project CHATA (Concepts of History and Teaching Approaches, 7-14). Retrieved from: http://files.eric.ed.gov/fulltext/ED388531.pdf

Lee, P. (2005). Historical Literacy: Theory and Research. International Journal of Learning, Teaching and Research, 5 (1). Retrieved http://citeseerx.ist.psu.edu/viewdoc/download?doi=10.1.1.537.9346\&rep=rep1\&type=pdf

Levstik, L. S., Barton, K. C. (2015). Doing history: Investitaging with Children in Elementary and Middle Schools. Routledge (Fifth edition).

Levstik, L. S., Barton, K. C. (1994). They Still Use Some of Their Past: Historical Salience in Elementary Children's Chronological Thinking. Pretrieved from: http://files.eric.ed.gov/fulltext/ED382492.pdf

Pradinio ugdymo benroji programa (2008). pp. 223 - 255. Retrieved from: https://www.sac.smm.lt/wpcontent/uploads/2016/01/ugdpr_1priedas_pradinio-ugdymo-bendroji-programa.pdf

Seixas, P. (1996). Conceptualising the Growth of Historical Understandind. In D. R. Olson, N. Torrance (Eds.). The Handbook of Education and Human Development (pp. 765-783). Oxford. Retrieved from: http://www.culturahistorica.es/seixas/conceptualizing_growth.pdf

Stow, W., Haydn, T. (2000). Issues in the teaching of chronology. In Arthur, J., Phillips, R. (Eds.) Issues in the Oteaching of history. London: Routledge, p. 83-97.

Van Drie, J., Van Boxtel, C. (2008). Historical Reasoning: Towards a Framework for Analyzing Students' Reasoning about the Past. Educational Psychology Rewiew, 20(2), 87-110. doi: 10.1007/s10648-007-9056-1.

White, M. D., Marsh, E. E. (2006). Content Analysis: A Flexible Methodology. In LIBRARY TRENDS, 55(1), Summer 2006, “Research Methods” (ed. by Lynda M. Baker), pp. 22-45.

Wilschut, A. (2010). A Forgotten Key Concept? Time in Teaching and Learning History. In Applied Sciences Paper presented at the 21st International Congress of Historical Sciences, Amsterdam. Retrieved from: https://www.academia.edu/2571670/A_Forgotten_Key_Concept

Žemgulienè, A. (2017). 4-th graders' understanding of historical time: guidelines for updating the world studies curriculum. In Towards research-based education. Vilnius: Lietuvos edukologijos universiteto leidykla, ISBN 978-609-471-115-2, pp. 382-437.

Žemgulienè, A., Balcevič, N. (2017). Istorinio raštingumo gebejjimai pradinèse klasèse: 3-4 klasès mokinių istorinio laiko tėkmès supratimas. In. Pasaulis vaikui: ugdymo realijos ir perspektyvos: tęstinis mokslo straipsniu leidinys. T. 6. Vilnius: Lietuvos edukologijos universiteto leidykla, ISSN 2538-7057, pp. 144-175. 